\title{
POLA KEPEMIMPINAN KEPALA DESA DAN PENGARUHNYA TERHADAP KEHIDUPAN UMAT BERAGAMA (STUDI DI DESA BALUN KECAMATAN TURI KABUPATEN LAMONGAN)
}

\author{
Octavian Hendra Priyatno \& Anjar Mukti Wibowo*
}

\begin{abstract}
Abstrak
Penelitian ini bertujuan untuk mengetahui pola kepemimpinan kepala desa terhadap masyarakat lintas agama di Desa Balun Kecamatan Turi Kabupaten Lamongan.

Metode penelitian menggunakan metode kualitatif. Jenis penelitian yang dipakai yaitu penelitian lapangan (field study research). Sumber data berasal dari sumber data primer dan sekunder dengan teknik pengambilan data melalui observasi, wawancara, serta dokumentasi. Informan ditentukan melalui teknik bertujuan (purposive sample). Validasi untuk menguji kebenaran data yakni trianggulasi sumber, sedangkan analisis data menggunakan model analisis interaktif Miles dan Huberman.

Berdasarkan hasil penelitian diketahui pola kepemimpinan kepala desa terhadap masyarakat lintas agama di Desa Balun berorientasi pada perilaku kepemimpinan demokratis. Penekanan pola perilaku tersebut dapat mengakomodasi berbagai kepentingan golongan sehingga terjalin interaksi yang positif antara lembaga pemerintahan, lembaga kemasyarakatan, dan lembaga keagamaan. Kepemimpinan demokratis ini tercermin dalam berbagai aktivitas yang berlandaskan musyawarah dengan melibatkan masyarakat bersangkutan. Hasil penelitian lainnya ditemukan bahwa kerukunan umat beragama di Desa Balun tidak bisa dilepaskan dari prinsip kekeluargaan, pendidikan, kultur masyarakat, peranan tokoh agama, serta dukungan dari pemerintah desa. Selain itu, dalam mempertahankan kerukunan umat beragama di Desa Balun memerlukan kharakter kepemimpinan desa yang secara umum berkecenderungan komunikatif, fleksibel, terbuka, peduli, dan partisipatif untuk meminimalkan benih-benih konflik di tubuh masyarakat.
\end{abstract}

\section{Kata kunci: Pola Kepemimpinan, Kepala Desa, Kerukunan Umat Beragama}

Pendahuluan

Kharakteristik kemajemukan merupakan suatu hal yang tak bisa dipungkiri ketika berbicara perihal keIndonesia-an. Realita di atas tentu dipengaruhi oleh perspektif fundamental yang menyebabkan Indonesia diselimuti keberagaman, sehingga bangsa ini memiliki keunikan tersendiri dari bangsa-bangsa lain di belahan bumi manapun.
Perspektif fundamentalis yang dimaksud dapat ditinjau dari sisi geografis maupun dari segi historisitas. Dua ranah tersebut memiliki efek dominan dalam terbentuknya sebuah karakter bangsa yang majemuk. Tinjauan dari sisi geografis menyatakan bahwa Indonesia merupakan negara yang terdiri dari gugusan kepulauan yang berpengaruh besar terhadap terciptanya pluralitas suku bangsa di negeri ini. 
Konsekuensi dari faktor geografis tersebut mampu menimbulkan komposisi ragam budaya yang berbeda. Posisi silang Indonesia yang terletak antara benua Asia dan Australia serta Samudera Pasifik dan Samudera Indonesia turut serta menambah beragamnya budaya negeri ini. Di masa kuno, jalur tersebut merupakan kawasan pelayaran serta perdagangan internasional yang sangat ramai. Kondisi demikian menurut Liem (dalam Nasikun 2007: 46) sangat mempengaruhi pluralitas agama dalam kehidupan masyarakat Indonesia. Statement ini pula mendasari sudah sejak lama masyarakat Indonesia mendapat pengaruh lintas budaya yang dibawa oleh bangsa lain melalui berbagai proses mediasi atau saluran tertentu.

Ditinjau dari segi historisitas, jauh sebelum terbentuknya NKRI yang terikat dalam satu-kesatuan politik (17 Agustus 1945), Indonesia telah mengalami proses rekonstruksi pengalaman sejarah yang begitu panjang. Mulai dari zaman prasejarah Indonesia, kemudian memasuki zaman kuno yang dihegemoni oleh kerajaan Sriwijaya, lalu disusul oleh kejayaan Majapahit yang tersohor hingga mancanegara. Selanjutnya, memasuki zaman Indonesia baru dipenuhi oleh rentetan kerajaan Islam, kekuasaan Imperialisme dan Kolonialisme Barat, pergerakan nasional, hingga masa kemerdekaan serta mempertahankan kemerdekaan. Semua itu merupakan bagian dari dinamika pengalaman historis yang merupakan bagian dari proses integrasi dan turut membentuk kharakteristik bangsa Indonesia.

Proses panjang perjalanan bangsa Indonesia dalam rangka menyatukan visi dan identitas bersama, tidak serta merta mengalami jalan yang mulus. Benturan kepentingan ideologi, gejolak antar kekuatan politik, disertai arus globalisasi yang begitu deras menimbulkan berbagai ketidaksepahaman. Ditambah pula kondisi masyarakat yang berbeda-beda (SARA) ketika berinteraksi satu sama lain memungkinkan untuk membuka jalan konflik semakin melebar.

Konflik dalam kehidupan masyarakat harus dipahami sebagai bagian dari proses dinamika interaksi manusia yang bersifat konstruktif jika mampu diatasi dengan kepemimpinan elegan melalui komunikasi yang positif. Salah satu dari sekian problematika krusial yang melanda negeri ini di era reformasi dalam kultur masyarakat majemuk seperti Indonesia ialah krisis kepercayaan terhadap pemimpin. Hubungan antara jalannya 
pemerintahan dengan faktor kepemimpinan merupakan suatu sistem yang tak bisa dihindarkan ketika masyarakat menginginkan progresifitas dalam tatanan kehidupan yang dipercayakan pada seorang public figure (pemimpin).

Seperti halnya kondisi plural yang dijelaskan sebelumnya, terdapat sebuah wilayah di kawasan Lamongan yang di dalamnya dihuni oleh masyarakat dengan kultur keyakinan beragam. Miniatur ke-Indonesia-an tersebut dapat ditemui di Desa Balun Kecamatan Turi Kabupaten Lamongan. Sebuah desa yang masyarakatnya memiliki heterogenitas dalam hal berkeyakinan (Islam, Kristen, Hindu) namun mampu mempertahankan eksistensi keberadaan sistem sosial yang telah dibangun selama bertahun-tahun. Kehidupan bermasyarakat di desa tersebut berbalut unsur ke-bhineka-an yang kuat disertai aroma kehidupan beragama yang kental. Kerukunan umat beragama sangat terasa tatkala disuguhkan dengan pemandangan masing-masing tempat ibadah (masjid, gereja, pura) yang dibangun dengan jarak relatif berdekatan. Hal ini mengasumsikan bahwa pengelolaan masyarakat desa dengan potret kharakteristik yang tak jauh dari deskripsi kemajemukan masyarakat
Indonesia itu sendiri memerlukan kepemimpinan desa yang ideal. Menurut pandangan Kaloh (2010: 12), pemimpin yang terbuka dan luwes adalah pemimpin yang tidak terikat pada tingkat, kedudukan, warna kulit, status dan lainnya. Seorang pemimpin, merupakan figur sentral yang bersinergis dalam menentukan efektivitas pencapaian sebuah tujuan atau cita-cita bersama melalui peranannya. Sedangkan identitas kesatuan masyarakat hukum yang terdapat di desa, merupakan suatu sistem mendasar kemasyarakatan yang begitu kuat. Melihat kenyataan demikian, desa dapat menjadi sebuah pijakan kuat dalam upaya mengembangkan sistem politik, ekonomi, sosial-budaya, dan hankam yang stabil (Ari Dwipayana dkk, 2006: 2). Oleh karena itu, menarik untuk diteliti lebih mendalam, berkaitan interaksi kepala desa (pemimpin) dengan masyarakat desa Balun yang tergolong multikultur (lintas agama) ditinjau dari sudut pandang pola kepemimpinan (politik) yang diterapkan.

Penelitian ini dilaksanakan untuk memperoleh gambaran yang memadai dan komprehensif mengenai pola kepemimpinan kepala desa terhadap masyarakat lintas agama di Desa Balun 
Kecamatan Turi Kabupaten Lamongan.

Hasil penelitian ini diharapkan dapat bermanfaat bagi:

1. Mahasiswa Program Studi Pendidikan Sejarah FPIPS IKIP PGRI MADIUN. Penelitian ini dapat memberikan sumbangsih dalam perspektif sejarah lokal, serta bahan kajian tentang studi pola kepemimpinan kepala desa lebih lanjut.

2. Masyarakat umum, hasil penelitian ini dapat memberikan gambaran tentang peran agama, budaya, dan

\section{Tinjauan Pustaka}

\section{A. Konsep kepemimpinan}

\section{Definisi Kepemimpinan}

Setiap individu memilki hasrat untuk menempatkan diri layaknya individu lain. Akan tetapi, hanya sebagian kecil di antara mereka yang mampu mewujudkannya. Sebagian kecil dari mereka yang mampu mewujudkan hasrat tersebut dalam kehidupan, umumnya menjadi pimpinan. Bagi mereka yang memiliki hasrat terpendam atau dengan kata lain tidak mampu mewujudkannya dalam kehidupan, berusaha mewujudkannya dengan jalan mengadakan identifikasi dengan pimpinannya. Harapannya kepemimpinan

untuk

memperkokoh

nilai-nilai

kharakteristik kebangsaan agar tidak menjadi korban dalam transformasi global.

3. Bagi pemerintah, khususnya Pemerintah Daerah Lamongan, dapat dijadikan bahan untuk mengambil kebijakan dalam pembangunan baik fisik maupun mental, terutama yang berkaitan dengan masalah kerukunan antar umat beragama.

mereka memiliki sikap dan tingkah laku yang sama. Itulah asal mula timbulnya kepemimpinan menurut Sigmund Freud (dalam Slamet Santosa, 2010: 231-232). Asal mula kepemimpinan tersebut muncul dan berkembang sebagai akibat dari struktur dinamika sosial yang cenderung kurang stabil.

Kepemimpinan adalah kegiatan untuk mempengaruhi orang lain, atau seni mempengaruhi perilaku manusia baik perorangan maupun kelompok (Miftah Thoha, 1983: 9). Kepemimpinan memiliki perbedaan dengan manajemen. Secara umum kepemimpinan dapat berlangsung dimanapun dan oleh siapapun, asalkan terdapat pengaruh seseorang untuk 
mencapai tujuan tertentu. Kepemimpinan memiliki arti yang lebih luas daripada manajemen, karena tidak harus berbenturan dengan struktur atau tata aturan birokrasi suatu organisasi.

Tannenbaum (dalam Slamet Santosa 1992: 57) berpendapat bahwa kepemimpinan merupakan pengaruh antara orang dalam kancahnya situasi langsung melalui proses komunikasi yang terarah untuk memperoleh tujuan khusus maupun tujuan umum. Kepemimpinan merupakan suatu proses mempengaruhi aktivitas dari individu atau kelompok untuk mencapai tujuan dalam situasi tertentu. Dari definisi tersebut, kepemimpinan dapat dilihat sebagai proses, bukan orang. Proses dalam kepemimpinan meliputi tiga faktor, yaitu pemimpin, pengikut, dan faktor situasi (Gitosudarmo dan Sudita, 2000: 127-128).

Sedangkan menurut Bimo Walgito (2007: 102), dalam sebuah kepemimpinan selalu terdiri atas beberapa variabel. Setidaknya dalam sebuah kepemimpinan terdapat enam variabel antara lain ada seorang pemimpin (posisi sekaligus subyek), kelompok yang dipimpin (obyek), ada tujuan atau sasaran (arah), ada aktivitasnya (peranan), interaksi (hubungan), dan otoritas (power).

Dari uraian pendapat para ahli di atas, kepemimpinan dapat diartikan sebagai proses dinamika interaksi sosial dalam kelompok manusia yang bertitik tolak pada figur, beradaptasi dengan situasi/kondisi lingkungan, sekaligus memuat unsur-unsur mempengaruhi maupun dipengaruhi yang dapat memunculkan aksi-reaksi melalui bentuk komunikasi tertentu demi tercapainya cita-cita bersama (organisasi).

Secara sederhana, jiwa kepemimpinan yang ada dalam seorang pemimpin (leader) dibentuk oleh faktor internal dan eksternal. Faktor internal yang dimaksud merupakan anugerah Tuhan yang dibawa sejak lahir, seperti bakat alami kepemimpinan (talent), daya tarik (charisma), kewibawaan (power), dan sebagainya. Di samping itu, faktor eksternal juga memiliki andil dalam merekonstruksi jiwa kepemimpinan lebih lanjut. Faktor eksternal yang dimaksud ialah pengaruh dari luar individu yang bersangkutan, seperti pendidikan, 
situasi dan kondisi lingkungan, pengalaman, dan sebagainya.

Dari statement tersebut, bisa dimengerti bahwa muncul dan berkembangnya seorang pemimpin merupakan hasil dari interaksi sosial antara diri pemimpin (internal) dengan anggota kelompok yang dipimpin (eksternal) dalam situasi, kondisi, serta tuntutan lingkungan ekologisnya. Dengan kata lain kepemimpinan dapat bekerja sebagai berikut; pemimpin mempengaruhi pengikut dan lingkungannya, sebaliknya pengikut dan lingkungan juga dapat mempengaruhi pemimpin.

\section{Kepemimpinan Kepala Desa}

Kepemimpinan kepala desa adalah cara atau implementasi tindak perilaku kepala desa dalam mempengaruhi, mengarahkan, mendorong, sekaligus memobilisasi segenap elemen masyarakat desa untuk bekerja atau berperan serta mencapai tujuan yang ditetapkan. Menurut Mc. Kinsey (dalam Rahardjo, 2006: 126-127), keberhasilan Kepala Desa dalam memimpin desanya secara efektif mencakup hubungan yang konsisten dari tujuh faktor, yaitu struktur, style, sistem, skill, strategi, dan superordinate goal.

Cara-cara atau usaha kepala desa mengelola masyarakat juga bergantung pada respon dari dalam dirinya. Respon merupakan bentuk dari perilaku seseorang (Soerjono Soekanto, 1993: 202). Penjelasan demikian akan mudah dimengerti melalui sebuah contoh di lapangan. Misalnya, apabila seseorang menemui perselisihan yang terjadi antara dua orang atau lebih. Keinginan untuk menyelesaikan perselisihan, keinginan untuk tidak mengacuhkan, ataupun keinginannya untuk mempertajam perselisihan, itu merupakan pengertian dari sebuah kepribadian. Sedangkan tindakan dalam mewujudkan keinginannya tersebut, itulah merupakan penjelasan dari sebuah perilaku. Perilaku yang memiliki pengaruh tertentu bisa dikatakan mengacu pada perilaku kepemimpinan (gaya kepemimpinan), yakni sebuah pola menyeluruh dari tindakan seorang pemimpin, baik tampak maupun tidak oleh bawahannya yang mampu memunculkan persepsi tersendiri pada pengikutpengikutnya. 
Reddin (dalam Kartono, 2008: 34), menentukan gaya kepemimpinan atas tiga pola dasar, yaitu berorientasi tugas, berorientasi pada hubungan, dan berorientasi pada hasil yang efektif. Berdasarkan ketiga pola dasar di atas akan berwujud dalam tiga tipe pokok kepemimpinan antara lain kepemimpinan otoriter, kepemimpinan kendali bebas, dan kepemimpinan demokratis (Veithzal Rifai, 2008: 56-57). Masing-masing tipe kepemimpinan memiliki relevansi dengan kepemimpinan pedesaan dengan ciri sebagai berikut:

1) Kepemimpinan otoriter

a. Pemimpin menentukan segala kegiatan kelompok secara sepihak,

b. Pengikut sama sekali tidak diajak untuk ikut serta merumuskan tujuan kelompok dan cara-cara untuk mencapai tujuan tersebut,

c. Pemimpin terpisah dari kelompok dan seakan-akan tidak ikut dalam proses interaksi di dalam kelompok tersebut.

2) Kepemimpinan demokratis

a. Secara musyawarah dan mufakat pemimpin mengajak warga atau anggota kelompok untuk ikut serta merumuskan tujuan-tujuan yang harus dicapai kelompok, serta caracara untuk mencapai tujuantujuan tersebut,

b. Pemimpin secara aktif memberikan saran dan petunjuk-petunjuk,

c. Ada kritik positif, baik dari pemimpin maupun pengikutpengikut,

d. Pemimpin secara aktif ikut berpartisipasi di dalam kegiatan-kegiatan kelompok.

3) Kepemimpinan bebas

a. Pemimpin menjalankan peranannya secara pasif,

b. Penentuan tujuan yang akan dicapai kelompok sepenuhnya diserahkan pada kelompok,

c. Pemimpin hanya menyediakan sarana yang diperlukan kelompok,

d. Pemimpin berada di tengahtengah kelompok, namun dia hanya berperan sebagai penonton (Soerjono Soekanto, 2012: 257).

Pada prakteknya di lapangan, ketiganya akan saling mengisi atau menunjang satu sama lain dengan beradaptasi pada situasi dan kondisi sehingga akan menghasilkan kepemimpinan yang 
efektif. Kharakter kepemimpinan kepala desa akan memiliki ke-khasannya masing-masing bergantung pada situasi dan kondisi lingkungan kerja (social basic) kepala desa bersangkutan. Maka, pola kepemimpinan alternatif kepala desa sebagai kepemimpinan lokal (local leadership) bisa jadi berbedabeda di tiap daerah (Rahardjo, 2006: 130).

\section{B. Kerukunan Umat Beragama}

Kata rukun dapat mengacu pada dua pengertian, yaitu sebagai keadaan dan sebagai tindakan. Dalam pengertian yang pertama, rukun berarti dalam keadaan selaras, tenang, tentram, tanpa perselisihan dan pertentangan. Di sisi lain, rukun mengacu pada cara bertindak untuk menghilangkan tanda-tanda ketegangan dalam masyarakat atau antara pribadipribadi sehingga hubungan sosial tetap kelihatan selaras dan baik. Unsur-unsur yang mungkin menimbulkan perselisihan dan keresahan, diupayakan untuk disingkirkan. Penjelasan di atas mendeskripsikan bahwa kerukunan memiliki korelasi antara kondisi sosial dan individual (Magnis dalam Poerwanto, 2000: 222).
Konsep kerukunan umat beragama bagi masyarakat Indonesia secara tegas dapat ditemukan dalam Pancasila yang juga merupakan dasar ideologi sekaligus falsafah negara. Implementasi nilai-nilai kerukunan umat beragama di Indonesia yang berlandaskan Pancasila, mengacu pada sila Ketuhanan Yang Maha Esa dan sila Persatuan Indonesia. Konsepsi ini diharapkan mampu mengikat umat beragama dalam konteks kebangsaan untuk menghindari konflik yang bernafaskan agama hingga pada akhirnya berbuah kerukunan.

Ketuhanan Yang Maha Esa ditempatkan sebagai sila yang pertama dalam dasar negara Pancasila. Berarti, bangsa Indonesia menuju pada perwujudan hidup manusia yang sesuai dengan perintahNya. Ketuhanan yang Maha Esa merupakan konsep perlindungan dan penghormatan umat beragama di Indonesia, sekaligus pengakuan atas kepercayaan pada Tuhan yang esa serta penolakan paham Atheis yang tidak mengakui keberadaan Tuhan. Driyarkara (dalam Tilaar, 2007: 211), menyatakan pada dasarnya sila-sila Pancasila semuanya 
diarahkan pada kehidupan kemanusiaan yang membutuhkan hidup kerohanian yaitu hubungannya dengan maha Pencipta serta hidup bersama dengan sesama dalam masyarakat yang adil dan makmur.

Sila selanjutnya yakni Persatuan Indonesia. Konsep ini sangat dibutuhkan Indonesia sebagai negara dengan kharakteristik majemuk (suku, agama, ras, dan antar golongan) di dalamnya. Cita-cita yang akan dibangun oleh negara Indonesia bukanlah sebuah masyarakat bangsa majemuk seperti yang digambarkan Furnival, akan tetapi satu masyarakat Bhineka Tunggal Ika. Yaitu sebuah masyarakat bangsa yang terdiri dari berbagai kelompok suku-bangsa dengan hak kulturalnya masing-masing (Amri Marzali, 2007: 214).

\section{Kalimat Bhineka Tunggal} Ika merupakan pengejawantahan kondisi sosial masyarakat Indonesia yang sebenarnya di masa lampau. Perjalanan sejarah bangsa Indonesialah yang mencuatkan fakta dan realitas keberagaman yang harus diterima bersama. Apabila semangat persatuan di masa silam mampu tercapai, seharusnya upaya untuk meneruskan cita-cita tersebut bisa terwujud pada kehidupan berbangsa dan bernegara masa kini dalam bingkai keragaman. Semboyan Bhineka Tunggal Ika (dalam Sutasoma) harus mampu dijiwai dan dipahami oleh masyarakat Indonesia dalam ranah persatuan bangsa jika menginginkan pencapaian kualitas masyarakat yang lebih baik. Pijakan ini serupa dengan yang diungkapkan oleh Slamet Mulyana (1979) dalam tafsir sejarah Nagara Kretagama. Bahwasannya, Maha Patih Gadjah Mada di masa lampau lebih mengutamakan kemakmuran dan persatuan rakyat di bawah panji Majapahit terlepas dari berbagai perbedaan keyakinan dalam beragama.

Konsep selanjutnya merujuk pada Tri Kerukunan Umat Beragama, yakni kerukunan intern umat beragama, kerukunan antar umat beragama, dan kerukunan antar umat beragama dengan pemerintah. Konsep ini pada hakekatnya juga didasari oleh sumber dari segala sumber hukum di Indonesia, yakni Pancasila. Di samping itu, jaminan untuk beragama di Indonesia telah diatur 
oleh pemerintah. Sesuai dengan yang tercantum pada UUD 1945 Bab XI Pasal 29 Ayat (2); Negara menjamin kemerdekaan tiap-tiap penduduk untuk memeluk agamanya masing-masing dan untuk beribadat menurut agamanya dan kepercayaannya itu. Artinya, pernyataan tersebut memposisikan agama dan syariatnya untuk dihormati dalam nilai asasi kehidupan berbangsa dan bernegara. Sejalan dengan itu, Denny (2006: 392) menyatakan prinsip-prinsip keagamaan setiap agama menjadi benar jika diterapkan dalam komunitas agama itu sendiri, namun menjadi problematik jika diterapkan kepada negara yang memiliki komunitas yang beragam. Yang berkewajiban menjalankan prinsip-prinsip agama adalah komunitas agama itu sendiri (dan para pemeluknya), bukan negara. Negara hanya berkewajiban menjalankan prinsip moral umum yang disepakati oleh semua agama, seperti pemerintahan yang bersih, pemimpin yang berintegrasi, dan kehendak baik.

Lebih lanjut, diatur juga dalam UU RI No. 39 Tahun 1999 tentang HAM Bab II Pasal 4, yang berbunyi; hak untuk hidup, hak untuk tidak disiksa, hak kebebasan pribadi, pikiran dan hati nurani, hak beragama, hak untuk tidak diperbudak, hak untuk diakui sebagai pribadi dan persamaan di hadapan hukum, dan hak untuk tidak dituntut atas dasar hukum yang berlaku surut adalah hak asasi manusia yang tidak dapat dikurangi dalam keadaan apapun dan oleh siapapun. Dengan terciptanya tri kerukunan umat beragama, diharapkan lebih memantapkan stabilitas nasional dan semakin memperkokoh persatuan dan kesatuan bangsa.

\section{Desa}

Desa merupakan sebutan secara umum untuk organisasi pemerintah terendah yang ada di tiap daerah kabupaten dalam rangka penyelenggaraan pemerintahan di wilayah NKRI. Menurut Unang Soenardjo (dalam Nurcholis, 2011: 4) desa adalah suatu kesatuan masyarakat bedasarkan adat dan hukum adat yang menetap dalam suatu wilayah yang tertentu batas-batasnya; memiliki ikatan lahir dan batin yang sangat kuat, baik karena seketurunan maupun karena samasama memiliki kepentingan politik, ekonomi, sosial dan keamanan; 
memiliki susunan pengurus yang dipilih bersama; memiliki kekayaan dalam jumlah tertentu dan berhak menyelenggarakan urusan rumah tangga sendiri.

Sapari Imam Asy'ari (1993: 93-94) memberikan batasan pengertian dengan dasar pemikiran dan kharakteristik yaitu aspek morfologi, aspek jumlah penduduk, aspek ekonomi, dan aspek sosial budaya. Dilihat dari aspek morfologi, desa adalah pemanfaatan tanah atau lahan oleh penduduk atau masyarakat yang bersifat agraris, serta bangunan rumah tinggal yang terpancar atau jarang. Dilihat dari aspek jumlah penduduk, maka desa didiami oleh sejumlah kecil penduduk dengan kepadatan yang rendah. Dilihat dari aspek ekonomi, desa adalah wilayah yang penduduk atau masyarakatnya bermata pencaharian pokok di bidang pertanian, bercocok tanam atau agraris, dan nelayan. Sedangkan jika dilihat dari segi sosial budaya, desa itu tampak dari hubungan sosial antar penduduknya yang bersifat khas, yakni hubungan kekeluargaan, bersifat pribadi, tidak banyak pilihan dan kurang tampak adanya pengkotaan, bersifat homogen, serta bergotong royong.

Merujuk pada UU No. 32 Tahun 2004 Bab I Pasal I angka 12 yang merevisi atas UU No. 22 Tahun 1999 merumuskan definisi desa sebagai berikut; "Desa atau yang disebut dengan nama lain, yang selanjutnya disebut desa, adalah kesatuan masyarakat hukum yang memiliki batas-batas wilayah yang berwenang mengatur dan mengurus kepentingan masyarakat setempat, berdasarkan asal-usul dan adat istiadat setempat yang diakui dan dihormati dalam sistem pemerintahan Negara Kesatuan Republik Indonesia." Beberapa ciri masyarakat desa menurut Nurani Soyomukti (2010: 307-308) antara lain; warga pedesaan mempunyai hubungan erat dan mendalam ketimbang hubungan mereka dengan warga pedesaan lainnya, sistem kehidupan biasanya berkelompok berdasarkan kekeluargaan, warga pedesaan umumnya mengandalkan hidupnya dari pertanian, sistem gotong-royong, pembagian kerja tidak berdasarkan keahlian, cara bertani sangat tradisional dan tidak efisien karena belum mengenal mekanisasi dalam pertanian, 
golongan orang tua dalam masyarakat pedesaan memegang peranan penting.

Menurut Nasikun, tipologi desa dapat diketahui dengan menghubungkan kegiatan pokok masyarakat dalam pemenuhan kebutuhan hidup sehari-hari (desa pertanian, desa industri, desa nelayan atau desa pantai). Selain itu, tipologi desa juga dapat dilihat dari pola pemukiman dan tipologi desa yang dapat dilihat dari perkembangan

masyarakat.Tipologi desa berdasarkan perkembangan masyarakat yang diuraikan oleh Nasikun (dalam Leibo, 1990: 1011) sesuai dengan PMD Depdagri (1972) antara lain:

1) Desa Tradisional (pra desa) Mayoritas ditemui pada masyarakat suku pedalaman. Kehidupan seperti bercocok tanam, cara pemeliharaan kesehatan, cara memasak makanan, dan sebagainya masih sangat tergantung pada alam.

2) Desa Swadaya

Kondisi desa relatif statis serta bergantung keterampilan pemimpinnya dalam pengelolaan desa, kedudukan seseorang dinilai dari keturunan dan kepemilikan luasnya lahan. Kepemilikan lahan yang dimaksud baik untuk tempat bermukim maupun untuk persawahan/perkebunan sebagai pusat mata pencaharian.

3) Desa Swakarya Keadaan desa mulai disentuh anasir luar berupa program inovasi desa, warna demokrasi serta mobilisasi sosial dalam kehidupan masyarakat sudah mulai tumbuh, ukuran penilaian masyarakat tidak lagi pada keturunan dan kepemilikan lahan tetapi pada karya, jasa, serta keterampilan tiap individu.

4) Desa Swasembada

Keadaan masyarakat telah sedemikian maju yang ditandai dengan dikenalnya mekanisme teknologi pertanian modern. Partisipasi masyarakat dalam hal pembangunan dirasa lebih besar dan aktif sesuai dengan skill dan kapasitas pada bidangnya. Memiliki kelebihan hasil desa sehingga mampu "mengekspor" ke luar.

5) Desa Pancasila 
Tipe desa ideal sesuai dengan cita-cita bersama yang berasaskan Pancasila dengan menjunjung tinggi tercapainya masyarakat adil dan makmur dalam segala bidang kehidupan.

\section{Metode Penelitian}

Penelitian ini menggunakan metode kualitatif. Penelitian kualitatif merupakan prosedur penelitian yang menghasilkan data deskriptif berupa kata-kata tertulis atau lisan dari orangorang dan perilaku yang dapat diamati (Margono, 2004: 36). Secara sederhana metode kualitatif dapat digunakan peneliti untuk membantu mengenal subyek secara pribadi, sehingga peneliti dapat melihat, mendengar dan merasakan dinamika yang terjadi pada individu dalam suatu kelompok. Sedangkan jenis penelitian yang dipakai menggunakan penelitian lapangan (field study research). Jenis penelitian ini selain membantu peneliti dalam memahami situasi dan kondisi obyek yang diteliti, juga membantu dalam mengidentifikasi secara detail dan mendalam terhadap subyek yang menjadi acuan inti dalam penelitian.

$$
\text { Metode }
$$

kualitatif

berkecenderungan pada pendekatan fenomenologis. Pendekatan semacam ini berusaha untuk memahami makna dari berbagai peristiwa dan interaksi manusia di dalam situasinya yang khusus (H.B. Sutopo, 2006: 27). Perspektif fenomenologis menekankan peneliti untuk melihat berbagai aspek perilaku manusia secara komprehensif yang dapat menimbulkan interpretasi tersendiri melalui beragam informasi yang diperoleh.

Alasan pemilihan metode kualitatif yakni peneliti berusaha dalam menafsirkan segala pola perilaku aktivitas subyek yang diteliti melalui data dan fakta yang diperoleh, untuk kemudian direkonstruksi sesuai konsep pemahaman peneliti secara pribadi dalam bentuk narasi maupun deskripsi. Harapannya, penjelasan akan subyek yang diteliti dapat lebih mudah disampaikan maupun dipahami.

1. Sumber Data Penelitian

Sumber data yang digunakan berupa sumber data primer dan sekunder. Sumber data primer diperoleh dari hasil observasi dan wawancara dengan informan, sedangkan sumber data sekunder diperoleh dari sumber pustaka yang diambil dari jurnal ilmiah, maupun buku-buku induk yang relevan dengan kajian penelitian, arsip desa, serta dokumentasi.

2. Informan 
Informan dalam suatu populasi atau masyarakat yang sekiranya mampu mewakili secara keseluruhan dalam rangka melengkapi temuan data akan meningkatkan efektivitas waktu dan efisiensi kerja. Maka peneliti menggunakan teknik bertujuan (purposive sample).

3. Pengambilan Data

Teknik pengambilan data melalui observasi, wawancara, serta dokumentasi.

4. Teknik Keabsahan Data

Jenis trianggulasi yang dipakai dalam penelitian ini yaitu jenis trianggulasi data atau biasa disebut dengan trianggulasi sumber. Cara ini mengarahkan peneliti agar didalam mengumpulkan data, wajib menggunakan beragam sumber data yang tersedia.

5. Analisis Data

Untuk menganalisa data menggunakan analisis kualitatif model interaktif.

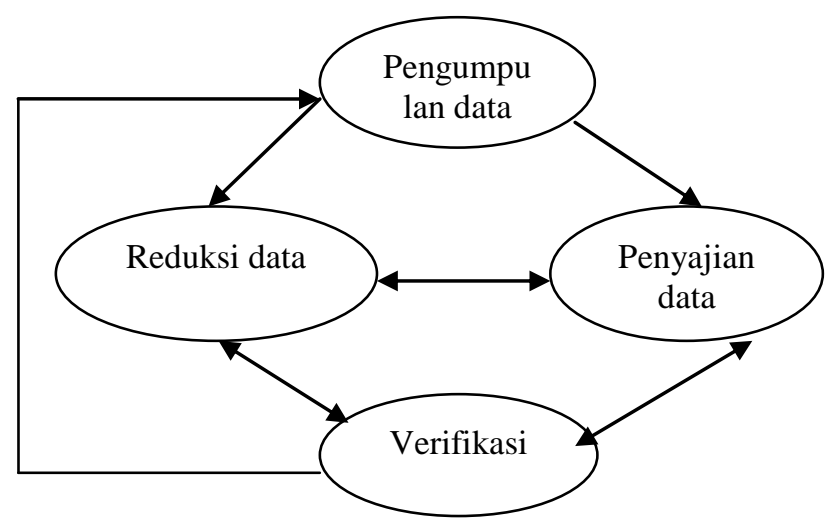

Bagan 2: Model Analisis Interaktif Miles dan Huberman

(H.B. Sutopo, 2006: 120)

\section{Hasil Penelitian dan Pembahasan}

\section{Kerukunan Umat Beragama di Desa Balun Kecamatan Turi Kabupaten Lamongan}

Keberagaman masyarakat di Desa Balun Kecamatan Turi Kabupaten Lamongan sebenarnya sudah berlangsung cukup lama. Menurut para tokoh agama (Adi, Sutris, Suwito) dan kepala desa setempat, terhitung sekitar tahun 1966 agama Kristen mulai melebarkan sayapnya, begitu pula umat Hindu dalam tempo yang hampir bersamaan, sedangkan untuk agama Islam sendiri sebelumnya telah dikenal sekaligus dipeluk oleh mayoritas masyarakat desa setempat.

Sejalan dengan waktu, proses interaksi yang terjalin di masyarakat dalam berbagai aktivitas cenderung terbuka. Identitas agama masing-masing golongan tidak serta merta menjadi sebuah justifikasi terhadap kepribadian seseorang. Secara umum masyarakat Desa Balun menganggap agama merupakan sebuah sarana dalam rangka mencapai kehidupan masyarakat yang lebih baik, sehingga apabila dalam kehidupan masyarakat terdapat 
pribadi-pribadi yang kurang baik, tidak lantas mereka harus membawa nama agama. Mereka meyakini hakekatnya apa yang diajarkan oleh agama adalah sesuatu yang baik untuk manusia. Perihal mengapa masih terdapat pribadi-pribadi yang menyalahi aturan agama, maka yang harus dipermasalahkan adalah kepribadiannya itu sendiri, bukan agama yang dipermasalahkan.

Analisis mengenai latar belakang masyarakat Desa Balun yang hidup dengan rukun dengan merujuk pada berbagai temuan data dapat dijabarkan diantaranya sebagai berikut:

\section{a. Prinsip kekeluargaan yang kuat}

Menurut keterangan Sudarjo (Kepala Desa Balun), kerukunan umat beragama di Desa Balun dilandasi atas dasar hubungan keluarga atau kekerabatan. Hampir seluruh penduduk masih memiliki ikatan keluarga satu sama lain. Ikatan keluarga ini sekaligus memberi identitas khusus terhadap adanya kesamaan ikatan sejarah.

Hubungan keluarga yang dimaksud tidak hanya dilandasi atas dasar kesamaan darah daging, akan tetapi juga dikarenakan kekerabatan yang terjalin oleh hubungan pernikahan yang berlanjut membentuk keluarga- keluarga baru. Salah satu orang yang berperan dalam sejarah Desa Balun itu sendiri adalah Sunan Tawang Alun I, yang meletakkan landasan nilai-nilai kehidupan yang disampaikan melalui sebuah suri tauladan. Masyarakat Desa Balun mampu memahami adanya kesamaan pendahulu, kesamaan nasib, dan kesamaan budaya serta tradisi dalam kehidupan bermasyarakat meski kenyataannya hidup dalam sebuah perbedaan.

\section{b. Pendidikan berbasis multikultur}

Satu hal yang perlu disoroti bahwasannya pendidikan kharakter tidak cukup diuraikan dengan retorika kata. Kharakter bisa dibentuk melalui sebuah aplikasi pembelajaran langsung di lapangan sejak dini, sehingga kondisi sosial yang dialami oleh individu akan membekas menjadi sebuah pengalaman dan diolah menjadi sebuah pembelajaran penting (keterangan Suwito, tokoh agama Islam).

Bisa dikatakan selain sebagai miniatur ke-Indonesia-an, Desa Balun juga bisa disebut sebagai laboratorium pembelajaran multikultur. Tujuan dari pendidikan kharakter tersebut tidak lain adalah untuk mengelola berbagai prasangka sosial dengan cara-cara yang positif melalui saling mengenal berbagai latar belakang tiap golongan yang berdasar atas ciri tertentu agar tercipta 
sebuah hubungan yang selaras dan kreatif.

\section{c. Kultur agama dan kehidupan masyarakat yang berkorelasi}

Terdapat tiga agama yang berkembang di desa ini, antara lain Islam yang beraliran Nahdlotul Ulama (NU), Kristen yang bercirikan Gereja Kristen Jawi Wetan (GKJW), dan agama Hindu yang bercorak Wisnu. Ketiga agama di desa setempat memegang nilai-nilai budaya lokal yang fleksibel, terbuka, dan cenderung memiliki kesamaan dari segi kultur sehingga minim untuk bersinggungan satu sama lain.

Begitu pula struktur masyarakat pedesaan yang masih kental dengan nilai-nilai tradisi, maka dirasa aliran agama-agama ini memiliki kecocokan dengan corak masyarakat pedesaan. Pada akhirnya, nuansa berbagai kultur masing-masing agama seakan melebur dan menjadi sebuah kharakteristik yang umum (melting pot) serta hidup dan berkembang dalam lintas ruang dan waktu.

\section{d. Peranan masing-masing tokoh agama}

Menurut Sudarjo (Kepala Desa Balun), tokoh agama memiliki peran besar dalam rangka membina kerukunan umat beragama. Kondisi masyarakat lintas agama desa setempat terlihat memiliki keterwakilan pada figur-figur ini.

Mediasi antar umat beragama seringkali dilakukan melalui tokohtokoh bersangkutan bila terdapat suatu musyawarah ataupun aktivitas dialogis, karena pada dasarnya tokoh-tokoh tersebut dianggap mampu mewakili golongan masyarakat dengan kriteria tertentu (keterangan Rokhim). Oleh karena itu, selama figur ini tidak bermasalah satu sama lain, selama itu pula umat beragama akan senantiasa percaya dan mengikuti jejak dari para tokoh agama tersebut untuk senantiasa ikut serta menciptakan kehidupan masyarakat yang lebih baik.

\section{e. Dukungan dari pemerintah desa (Kepala Desa)}

Disadari atau tidak, peran dari pemerintah desa dalam membina kerukunan umat beragama sangatlah strategis. Unsur-unsur pemerintahan desa seperti kepala desa memegang peranan sentral dalam keberlangsungan kerukunan umat beragama di Desa Balun. Bagaimana tidak, dalam hal ini Kepala Desa selaku pimpinan Pemerintahan Desa dituntut untuk peka, terbuka, dan komunikatif terhadap berbagai permasalahan yang menghinggapi masyarakat. Obyek sasaran pembangunan yang pertama hakekatnya adalah jiwa masyarakat. 
2. Pola Kepemimpinan Kepala Desa Balun Kecamatan Turi Kabupaten Lamongan

Perlu dicermati pula bahwasannya dalam mengemukakan masalah kepemimpinan terdapat perbedaan persepsi antara diri sendiri dengan orang lain mengenai gaya kepemimpinan. Apa yang diaplikasikan Kepala Desa Balun pada masyarakatnya akan memberi pengaruh, respon, penilaian, dan persepsi tersendiri dari masyarakat yang dipimpinnya, dalam hal ini masyarakat lintas agama di desa setempat. Persepsi mengenai gaya kepemimpinan kepala desa yang ditunjukkannya bisa saja berbeda dengan gaya kepemimpinan yang sesungguhnya. Maka, penilaian ini sangat bergantung seberapa dekat persepsi peneliti dengan persepsi masyarakat Desa Balun sebagai obyek (yang dikenai) secara umum.

Ditinjau dari segi perilaku kepemimpinan, pola perilaku Kepala Desa Balun cenderung mencerminkan gaya demokratis, dimana perilaku ini juga beradaptasi pada keadaan masyarakat bersangkutan (social basic). Nilai-nilai demokratis relevan dalam menghadapi keadaan yang bersifat multikultur sebagai bagian dari sebuah respon untuk menjawab berbagai kebijakan desa. Tanpa aspek-aspek demokratis, sangatlah mustahil untuk menampung berbagai aspirasi masyarakat yang juga memiliki berbagai kepentingan, misalnya dari umat Kristiani, umat Muslim, maupun umat Hindu.

Pola kepemimpinan Kepala Desa Balun yang memiliki pengaruh dalam menstabilkan keadaan masyarakat tidak serta merta datang begitu saja. Penjelasan tersebut dapat diterangkan melalui pendekatan social learning yang merupakan dasar dalam memberikan pengertian menyeluruh dalam memahami kepemimpinan kepala desa. Penekanan ini memiliki korelasi terhadap gaya demokratis Kepala Desa Balun, interaksi timbal balik masyarakat dengan pemerintahan desa, serta keberlangsungan kerukunan umat beragama di Desa Balun.

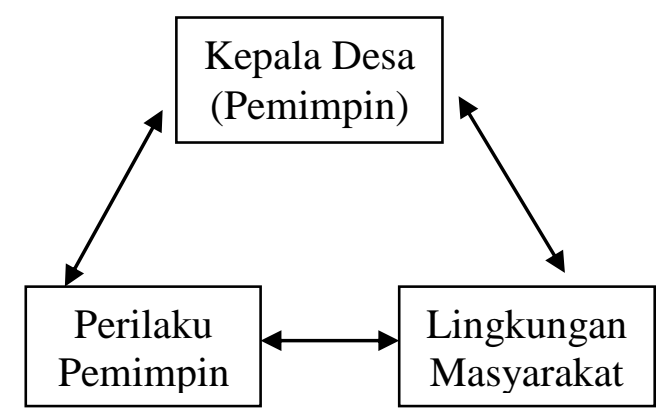


Bagan 3: Pendekatan Social Learning dalam Kepemimpinan (Adaptasi dari Thoha, 1983: 49)

Bagan 3 di atas menunjukkan bahwasannya Kepala Desa Balun berinteraksi dengan lingkungan masyarakatnya dalam berbagai aktivitas. Terdapat proses pertukaran antara Kepala Desa Balun dengan masyarakat desa setempat tentang pengembangan peranan dan pertukaran dalam sebuah kepemimpinan. Masyarakat secara aktif terlibat dalam proses kegiatan, dan bersama-sama dengan Kepala Desa Balun memusatkan perhatian pada perilaku masing-masing. Masyarakat pun juga melakukan hal demikian, sehingga terjadi refleksi atas masing-masing perilaku. Penjelasan ini memungkinkan terjadinya aplikasi nilainilai demokratis berupa musyawarah terhadap persoalan kemasyarakatan. Keduanya memiliki hubungan interaksi timbal balik yang positif dalam memperbaiki perilaku satu sama lain.

Kepemimpinan Kepala Desa Balun juga ditunjukkan sebagai suatu perilaku seseorang yang dapat dimengerti atas dua dimensi, yakni sebagai struktur pembuatan inisiatif atau perilaku tugas dan perhatian atau perilaku hubungan (Miftah Thoha, 1983: 38). Apabila melakukan pendekatan hubungan sosial, masyarakat dapat mempengaruhi pemimpin, pemimpin juga dapat mempengaruhi masyarakat. Masyarakat yang tidak dapat hidup dengan rukun dan terindikasi terdapat adanya permasalahan, pemimpin memiliki kecenderungan menekankan pada struktur pengambilan inisiatif (perilaku tugas). Akan tetapi apabila masyarakat dapat hidup dengan damai maka pemimpin berkecenderungan menekankan pada pemberian perhatian (perilaku hubungan).

Pada dasarnya, dalam mengembangkan sebuah pola kepemimpinan multikultur masyarakat di Desa Balun faktor penting terdapat pada masalah komunikasi. Apabila komunikasi berjalan dengan lancar dan berlangsung secara elegan, maka permasalahan-permasalahan yang ada akan cepat teratasi dan tidak semakin menjalar. Beberapa hal penting yang dapat dijadikan referensi untuk berpijak sebagai kepala desa yang membawahi masyarakat lintas agama seperti di Desa Balun Kecamatan Turi Kabupaten Lamongan secara umum tercermin sebagai berikut:

a) Mampu merangkul lembaga keagamaan, kemasyarakatan, dan pendidikan di wilayah kerjanya. 
Kepemimpinan desa

memerlukan pemimpin yang mampu menjalin komunikasi positif di berbagai lini. Kepemimpinan ini mampu membujuk, meyakinkan, dan mengajak anggota masyarakatnya untuk melakukan berbagai aktivitas pembangunan demi kesejahteraan masyarakat desa itu sendiri.

b) Musyawarah pembangunan tempat ibadah masing-masing agama maupun sarana prasarana fisik yang lain.

Musyawarah merupakan pencerminan dari aplikasi nilainilai luhur Pancasila, terutama Sila ke-4. Untuk menghasilkan kepemimpinan multikultur yang handal perlu sebuah kemampuan dalam menyesuaikan serta menampung aspirasi masyarakat, sehingga dapat diarahkan dalam partisipasi pembangunan pedesaan. Musyawarah sangat relevan dengan nilai-nilai demokratis, dimana musyawarah merupakan jalan dalam mengakomodasi berbagai perbedaan yang ada.

Kepedulian dalam hal
pembinaan
kemasyarakatan

Implementasi dalam pembinaan mental kemasyarakatan dalam hal masalah kerukunan umat beragama di Desa Balun tidak serta merta hanya merupakan kewajiban para tokoh agama. Akan tetapi sebagai pemimpin pemerintahan desa yang memiliki kewenangan lebih berdasarkan suarat keputusan yang ditetapkan, harus memiliki kepedulian dalam rangka mempertahankan semangat keberagaman.

Pembinaan mental kemasyarakatan tersebut terkait masalah hak dan kewajiban, larangan-larangan, toleransi, dan penggalangan partisipasi masyarakat untuk pembangunan, dan tentunya kerukunan umat beragama. Semua itu juga membutuhkan respon yang positif dari masyarakat. Pernyataan tersebut dapat diartikan bahwa kepemimpinan merupakan serangkaian kegiatan atau aktivitas pemimpin terkait kedudukan dan perilaku kepemimpinannya.

d) Keterbukaan dengan masyarakat maupun pihak luar.

Apabila pemerintah desa membuka diri dengan pihak luar akan mendatangkan keuntungan yang positif. Bertambahnya link atau jaringan merupakan salah satu akses menuju keberhasilan dan 
popularitas desa bersangkutan lebih lanjut.

Selain itu, banyak ragam pembelajaran menarik yang bisa membuka wawasan dari interaksi timbal balik dari masing-masing pihak. Harapannya dari sebuah keterbukaan tersebut akan berujung pada dialogis yang memiliki nilai-nilai yang positif untuk kebaikan umat manusia.

e) Kesediaan memfasilitasi suatu kegiatan demi kesejahteraan masyarakat desa.

Poin ini memiliki korelasi dengan poin sebelumnya, dimana kesediaan memfasilitasi suatu kegiatan harus didahului dengan adanya keterbukaan. Tanpa adanya keterbukaan dan keluwesan (fleksibelitas) maka suatu kegiatan yang sejatinya untuk kepentingan masyarakat desa tidak akan terakomodir dengan baik.

f) Komunikatif, baik itu kepada tokoh-tokoh agama khususnya, maupun ketika bersosialisasi dengan masyarakat secara umum.

Berbagai uraian mengenai hal-hal penting yang tercermin dari aktivitas interaksi Kepala Desa Balun, semua itu tidak akan berjalan dengan baik tanpa diimbangi dengan komunikasi yang baik pula. Kekuatan komunikasi merupakan kekuatan mengajak, mempengaruhi, dan meyakinkan. Karena pada dasarnya kepemimpinan juga sebagai proses antar hubungan atau interaksi antara pemimpin, byang dipimpin, dan situasi.

g) Kharakter yang dibentuk oleh latar belakang yang bersangkutan, baik itu dari segi pendidikan, keyakinan, pengalaman, maupun hal-hal yang lain.

Pengalaman akan membentuk kharakter seseorang. Telah diuraikan sebelumnya bahwasannya Kepala Desa Balun saat ini memiliki latar belakang seorang pemuda Hindu sebelum akhirnya beralih menjadi muallaf karena faktor pernikahan.

Kondisi tersebut akan mampu memberi warna tersendiri pada jiwa yang bersangkutan manakala terjun dalam sebuah kepemimpinan desa. Orang-orang dengan latar belakang tertentu disertai berbagai masukan pengalaman akan memiliki kualitas tersendiri di mata masyarakat. Oleh karena itu dapat dijelaskan bahwa kepemimpinan merupakan sesuatu 
yang melekat pada diri seorang pemimpin berupa sifat-sifat tertentu seperti kepribadian, kemampuan, dan kesanggupan.

\section{Kesimpulan dan Saran}

\section{Kesimpulan}

Pola kepemimpinan Kepala Desa Balun selaku pucuk pimpinan pemerintahan desa di Desa Balun Kecamatan Turi Lamongan harus memiliki keunggulan di ranah komunikasi untuk mengakomodasi berbagai perbedaan yang ada. Persepsi pola perilaku kepemimpinan (gaya kepemimpinan) kepala desa setempat cenderung mengarah pada kepemimpinan demokratis yang tercermin dalam berbagai aktivitas yang berlandaskan musyawarah dengan melibatkan masyarakat. Sedangkan kerukunan umat beragama di Desa Balun itu sendiri tidak bisa dilepaskan dari adanya prinsip kekeluargaan, pendidikan, kultur masyarakat, peranan tokoh agama, serta dukungan dari pemerintah desa setempat.

Beberapa hal dari pola kepemimpinan Kepala Desa Balun yang dapat dijadikan referensi berpijak kaitannya dengan masyarakat multikultur antara lain; mampu merangkul lembaga keagamaan, kemasyarakatan, dan pendidikan di wilayah kerjanya, musyawarah pembangunan dengan masyarakat, kepedulian dalam hal pembinaan mental kemasyarakatan, keterbukaan dengan masyarakat maupun pihak luar, kesediaan sebagai fasilitator suatu kegiatan, komunikatif, dan kharakter yang dibentuk oleh latar belakang bersangkutan.

\section{Saran}

\section{a. Bagi Pemerintah Kabupaten}

\section{Lamongan}

Dengan

keberadaan masyarakat multikultur di Desa Balun Kecamatan Turi Kabupaten Lamongan diharapkan pemerintah kabupaten terkait terus memberi apresiasi nyata, sosialisasi, sekaligus promosi tentang kehidupan kerukunan masyarakat umat beragama pada khalayak umum sebagai sebuah referensi pembelajaran penting tentang nilainilai kehidupan berbangsa dan bernegara berdasar Pancasila serta mengacu pada Tri Kerukunan Umat Beragama. Dengan demikian secara tidak langsung akan menarik minat masyarakat luas terhadap keunikan desa setempat untuk berwisata 
rokhani sekaligus menempa nilainilai kearifan dalam kehidupan bermasyarakat.

\section{b. Bagi Kepala Desa Balun}

\section{Kecamatan Turi Kabupaten}

\section{Lamongan}

Dengan studi pola kepemimpinan ini, diharapkan pola-pola kepemimpinan yang positif tetap bersandar pada sosial basic desa setempat meskipun pada akhirnya tiap Kepala Desa Balun selanjutnya memiliki kharakter yang khas dan beragam sesuai dengan latar belakang pendidikan, pengalaman, maupun keyakinan beragamanya.

\section{c. Bagi Masyarakat Setempat}

Dengan keberadaan sistem kemasyarakatan yang telah terbentuk cukup lama, maka masyarakat ini secara tidak langsung menjadi sebuah laboratorium pembelajaran kehidupan. Harapannya, masyarakat Desa Balun mampu mempertahankan kultur keberagaman dan mewariskan kerukunan umat beragama pada generasi selanjutnya, serta mampu mendeskripsikan pada masyarakat luas secara umum tentang nilainilai kehidupan yang ada di desa setempat.

\section{Daftar Pustaka}

AAGN Ari Dwipayana, dkk. 2006. Pembaharuan Desa Secara Partisipatif. Yogyakarta: Pustaka Pelajar.

Amri Marzali. 2007. Antropologi dan Pembangunan Indonesia. Jakarta: Kencana.

Bimo Walgito. 2008. Psikologi Kelompok. Yogyakarta: CV Andi Offset.

Denny J.A. 2006. Demokrasi Indonesia Visi dan Praktek. Jakarta: Pustaka Sinar Harapan.

H.A.R. Tilaar. 2007. Mengindonesia Etnisitas dan Identitas Bangsa Indonesia Tinjauan dari Perspektif Ilmu Pendidikan. Jakarta: PT Rineka Cipta.

H. B. Sutopo. 2006. Metodologi Penelitian Kualitatif. Surakarta: Universitas Sebelas Maret.

Hanif Nurcholis. Pertumbuhan dan Penyelenggaraan Pemerintahan Desa. Jakarta: Penerbit Erlangga.

Hari Poerwanto. 2000. Kebudayaan dan Lingkungan Dalam Perspektif Antropologi. Yogyakarta: Pustaka Pelajar.

Indriyo Gitosudarmo dan I Nyoman Sudita. 2000. Perilaku Keorganisasian. Yogyakarta: BPFE-Yogyakarta.

J. Kaloh. 2010. Kepemimpinan Kepala Daerah Pola Kegiatan, Kekuasaan, Perilaku Kepala Daerah dalam Pelaksanaan Otonomi Daerah. Jakarta: Sinar Grafika.

Jefta Leibo. 1990. Sosiologi Pedesaan. Yogyakarta: Andi Offset.

Kartini Kartono. 2008. Pemimpin dan Kepemimpinan Apakah Kepemimpinan Abnormal itu? Jakarta: PT RajaGrafindo Persada.

Margono. 2004. Metodologi Penelitian Pendidikan. Jakarta: PT Rineka Cipta. 
Miftah Thoha. 1983. Kepemimpinan dalam Manajemen Suatu Pendekatan Perilaku. Yogyakarta: CV Rajawali.

Nasikun. 2007. Sistem Sosial Indonesia. Jakarta: PT RajaGrafindo Persada.

Nurani Soyomukti. 2010. Pengantar Sosiologi: Dasar Analisis, Teori, dan Pendekatan Menuju Analisis Masalah-Masalah Sosial, Perubahan Sosial, dan KajianKajian Strategis. Yogyakarta: ARRuzz Media.

R. Bintarto. 1984. Interaksi Desa-Kota dan Permasalahannya. Jakarta: Ghalia Indonesia.

Rahardjo Adisasmita. 2006. Membangun Desa Partisipatif. Yogyakarta: Graha Ilmu.

Sapari Imam Asy'ari. 1993. Sosiologi Kota dan Desa. Surabaya: Usaha Nasional.

Slamet Santosa. 1992. Dinamika Kelompok. Jakarta: Bumi Aksara. 2010. Teori-Teori Psikologi Sosial. Bandung: PT Refika Aditama.

Soerjono Soekanto. 1993. Sosiologi Suatu Pengantar. Jakarta: PT RajaGrafindo Persada. 2012. Sosiologi Suatu Pengantar. Jakarta: PT RajaGrafindo Persada.

Veithzal Rivai. 2008. Kepemimpinan dan Perilaku Organisasi. Jakarta: PT RajaGrafindo Persada. 